\section{Provokatøren på «Yttersia»}

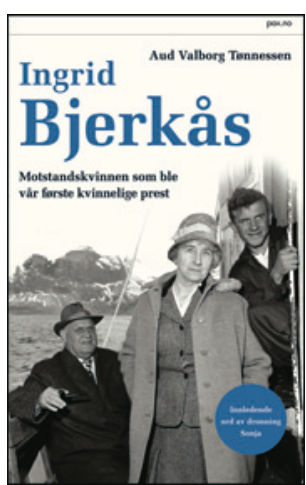

Aud Valborg Tønnessen

Ingrid Bjerkås

Motstandskvinnen som ble vår første kvinnelige prest.

209 s, ill, Oslo: Pax Forlag, 2014. Pris NOK 349

ISBN 978-82-530-3687-8

En kvinnelig teologiprofessor med norsk kirkehistorie som spesiale har skrevet en biografi om Norges første ordinerte kvinne, sognepresten på ytre Senja, Ingrid Bjerkås. Professoren har valgt en tradisjonell biografiform der vi følger hovedpersonen kronologisk fra fødsel til grav og ettermæle. Boken har to dramatiske høydepunkter. Det første er Ingrid Bjerkås' uredde antinazistiske aktiviteter under okkupasjonen. Hennes brev til Quisling og hennes møte med «Føreren» er interessant lesning, og vi må beundre hennes forsøk på å stanse Terbovens tale foran Slottet. Bjerkås' klare motstandsholdninger var så sterke og uten tanke på konsekvenser at Quislings livlege, Hans Eng, fant grunn til å diagnostisere henne som psykotisk et alvorlig tilfelle av «Jøssingismus». Et år på Grini var resultatet.

Først etter krigen, med voksne barn og nesten pensjonert revisormann, begynte hennes religiøse liv og overveielser. Boken skildrer støtten fra familie og venner under det teologiske studiet. Hun var ingen strålende akademiker, og hennes eksamener ble passert med nokså nødtørftige resultater. Men forfatteren skildrer et menneske med brennende religiøs overbevisning og et sterkt ønske om å kunne bruke sin utdanning i praktisk menighetsarbeid til nytte for sine medmennesker. Kampen for å få dette gjennomført skildres nettopp så dramatisk som det må ha vært. Menighetsfakultetet mobiliserte alle professorer og lavkirkelige organisasjoner til kamp mot den kvinnelige presten som «ville føre til kirkens undergang og oppløsning». Man blir i dag forundret over motstandernes forbitrelse og deres ufine metoder for å sverte en kvinnelig kollega. Biskop Schjelderup, som i 1961 ordinerte Bjerkås, fikk en liknende behandling. Overraskende er også den lunkne holdningen hennes kvinnelige teologiske kolleger viste. I løpet av femti år er altså bildet helt forandret: $30 \%$ av prestene er i dag kvinner, og Kirkens primas er en kvinne! Vi får tro at motstanderne har evnet å revurdere sine «gudegitte» standpunkter og handlinger.

Tiden på Senja for sognepresten og «præstkailln» er godt beskrevet og sier mye om Bjerkås' teologiske ståsted, hennes praktiske grep på prestegjerningen og hvor viktig støtten fra hennes pensjonerte ektemann var. Den mottakelsen presteparet fikk på Senja, sier også mye om rausheten blant befolkningen på «Yttersia».

Hans Engs herostratisk berømte diagnose av Bjerkås, «Jøssingismus anglemanicus paranoidformis», gjentas ofte i Engs noe forunderlige latin. I erklæringen bruker han også «Jøssingismus psykopathica». Boken har 22 relevante illustrasjoner, til sist et bilde av dronning Sonja som taler foran Bjerkås' byste ved Berg kirke. Talen er gjengitt som en innledning til boken.

Dette er en velskrevet, interessant og spennende biografi over en av vår tids fremste banebrytere for kvinnelig likestilling. Den kan varmt anbefales.

\section{Trenger leger å kunne noe om TENS?}

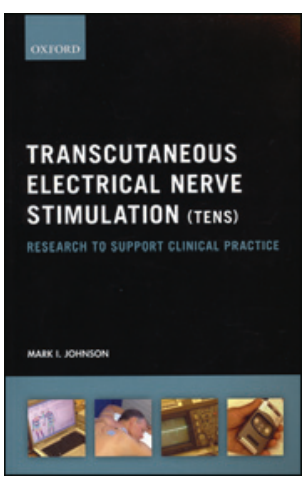

Mark I. Johnson

Transcutaneous electrical nerve stimulation (TENS)

Research to support clinical practice. $261 \mathrm{~s}$, tab, ill. Oxford: Oxford University Press, 2014 Pris GBP 35

ISBN 978-0-19-967327-8

Denne utgivelsen tar mål av seg å gi en oversikt over bruk av transkutan nervestimulering (TENS), primært for ulike yrkesgrupper som er involvert i bruk av denne typen apparater. Forfatteren ønsker å formidle evidensbasert kunnskap på området.

Boken er liten og lett, og får plass i en reiseveske. Den gir en god oversikt over de ulike variantene av TENS. De smertefysiologiske prinsippene bak metoden forklares godt og enkelt, og det tekniske grunnlaget presenteres på en grei måte. Praktiske råd om bruk, kontraindikasjoner og forsiktighetsregler formidles enkelt og tydelig. Avgrensningen mot andre former for nevromodulasjon er tatt opp i et eget kapittel.

Det vitenskapelige grunnlaget for TENS i smertebehandling gjennomgås kritisk i et eget kapitel, der det forholdsvis klart fremgår hva som er evidensbasert og hva som er mer erfaringsbasert. I et tilsvarende kapittel om TENS i behandling av ikke-smertefulle tilstander er det evidensbaserte grunnlaget noe mer springende, noe som dessverre også er tilfellet når forskjellene mellom de ulike TENS-varianter og -metoder beskrives i de andre kapitlene.

Boken vil med sitt akademiske språk neppe egne seg for pasienter flest, men interesserte lesere med høyere utdanning innenfor medisin, fysiologi eller tekniske fag vil kunne ha stort utbytte av den. Selv om det i Norge oftest er fysioterapeuter som starter og følger opp TENS-behandling, er det gode grunner til at leger bør sette seg inn i metoden, dens begrensninger og, ikke minst, kontraindikasjoner. Noen timer med denne boken er vel anvendt tid for leger som jobber med utredning og behandling av pasienter med smerter.

Kristian Bernhard Nilsen

Overlege og spesialist i klinisk nevrofysiologi, Oslo universitetssykehus 